\title{
THE EFFECT OF GOOD CORPORATE GOVERNANCE ON CORPORATE SOCIAL RESPONSIBILITY DISCLOSURE ON JAKARTA ISLAMIC INDEX
}

\author{
Erna Listyaningsih")1, Riska Dewi*), and Nur Baiti ${ }^{*}$ \\ *) Department of Management, Faculty of Economic, Universitas Malahayati \\ Jl. Pramuka No 27, Kemiling, Bandar Lampung 35152
}

\begin{abstract}
The previous research results show various disclosures of the effects of Good Corporate Governance on Corporate Social Responsibility. The objective of this study was to examine the effects of Good Corporate Governance on the Corporate Social Responsibility disclosure to companies incorporated in the Jakarta Islamic Index. Proxies of Good Corporate Governance in this research include the managerial ownership, institutional ownership, foreign ownership, size of the independent commissioner board, size of the audit committee, and concentrated share ownership. The samples used in this study were companies registered in the Jakarta Islamic Index and had information on Good Corporate Governance and applied the disclosure of Corporate Social Responsibility during the period of 2013-2016. The total of the samples used consisted of 23 companies for the four year period. Multiple linear regression test was conducted to analyze whether Good Corporate Governance influenced the disclosure of Corporate Social Responsibility. The results of this study show that the variables that affect the disclosure of Corporate Social Responsibility are managerial ownership, institutional ownership, and foreign ownership. However, there are three variables that do not affect the disclosure of Corporate Social Responsibility that is the size of the independent commissioner board, size of the audit committee, and concentrated share ownership.
\end{abstract}

Keywords: corporate social responsibility, good corporate governance, jakarta islamic index, regression

\begin{abstract}
Abstrak: Pada penelitian sebelumnya menghasilkan pengaruh Good Corporate Governance terhadap pengungkapan Corporate Social Responsibility yang bervariasi. Tujuan dari penelitian ini adalah untuk mengetahui pengaruh Good Corporate Governance terhadap pengungkapan Corporate Social Responsibility pada perusahaan-perusahaan yang tergabung dalam Jakarta Islamic Index. Proksi Good Corporate Governance dalam penelitian ini adalah kepemilikan manajerial, kepemilikan institusional, kepemilikan asing, ukuran dewan komisaris independen, ukuran komite audit dan kepemilikan saham terkonsentrasi. Sampel yang digunakan dalam studi ini adalah perusahaan yang terdaftar di Jakarta Islamic Index yang mempunyai informasi tentang Good Corporate Governance dan mengaplikasikan pengungkapan Corporate Social Responsibility selama periode 20132016. Total sampel yang digunakan adalah 23 perusahaan yang konsisten selama empat tahun. Uji regresi linear berganda dilakukan untuk menganalisis apakah Good Corporate Governance berpengaruh terhadap pengungkapan Corporate Social Responsibility. Hasil dari studi ini memperlihatkan bahwa variabel-variabel yang mempengaruhi pengungkapan Corporate Social Responsibility adalah kepemilikan manajerial, kepemilikan institusional, dan kepemilikan asing. Namun, terdapat tiga variabel yang tidak mempengaruhi pengungkapan Corporate Social Responsibility yaitu ukuran dewan komisaris independen, ukuran komite audit, dan kepemilikan saham terkonsentrasi.
\end{abstract}

Kata kunci: corporate social responsibility, good corporate governance, jakarta islamic index, regresi

${ }^{1}$ Corresponding author:

Email: ernatya04@yahoo.com 


\section{INTRODUCTION}

The implementation of Good Corporate Governance (GCG) is what companies need to do in the $21 \mathrm{st}$ century, where the GCG according to the Forum for Corporate Governance in Indonesia (FCGI) is a set of rules governing relationship among shareholders, managers, creditors, employees, and other stakeholders to balance their rights and obligations (Andypratama and Mustamu, 2013). To achieve this, the company is expected to apply the GCG principles as set out in the Indonesian GCG General Guidelines issued by the Capital Market Supervisory Agency (Bapepam), namely: transparency, accountability, responsibility, independence, fairness, and equality (Bapepam, 2010). Based on previous studies, GCG has influenced the disclosure of Corporate Social Responsibility (CSR) (Nussy, 2013, Ramdhaningsih and Utama, 2013; Ningrum, 2015; Nugroho and Yulianto, 2015; Wiyuda and Pramono, 2017).

CSR or corporate social responsibility is an obligation that must be implemented by the company, and it is a form of corporate responsibility and attitude to the environment and society. The benchmark of a company's CSR success is to advance the moral and ethical principles achieving the best results without losing any other community groups (Suaryana and Febriana, 2012).

CSR communicates the company to stakeholders through CSR Disclosure (Lindawati and Puspita, 2015). Also, CSR is a signal given by the management to all stakeholders including potential investors regarding the prospect of the company in the future and shows more values owned by the company for its concern on the economic, social and environmental impacts arising from the its activities. Disclosure of social, ethical, environmental and sustainable aspects is a way for companies to convey their accountability form to stakeholders (Susanti and Riharjo, 2013). If CSR disclosure is conducted on a sustainable basis by the company, it will provide many benefits for the company itself. The company's involvement on its social responsibility can improve access to capital, improve financial performance, reduce operating costs, improve image and reputation, increase sales and customer loyalty, and improve productivity and quality (Susanti and Raharjo, 2013). The importance of CSR's role in sustainable corporate business makes CSR to be adopted in the company's business strategy (Djunaedi et al. 2016). Therefore, the implementation of GCG and CSR disclosure if implemented properly and sustainably is expected to support the economic growth to continuously increase along with transparency of management of the company that the better and profitable many parties (Sukasih and Sugiyanto, 2017).

In Indonesia, disclosure of social and environmental responsibility in the annual report of the Limited Company has become an activity that must be stated in the annual report based on Law no. 40, 2007 and Bapepam-LK regulation No.X.K.6 (Lindawati and Puspita, 2015). The principles of GCG, among the others, are transparency, accountability, responsibility, independence, fairness and equality, and in Islamic teachings, these points become important principles in the activity and life of a Muslim (Ismanto, 2009); thus, the application of GCG in the sharia company becomes an inevitable necessity.

One of the Islamic indexes in Indonesia which has market capitalization that tends to increase since its establishment in 2000 is the Jakarta Islamic Index (JII). Table 1 shows an increasing trend of JII market capitalization from 2010-2016, although it decreased in 2015. This shows that JII is in demand by investors. Companies incorporated in JII are those that do not engage in activities such as gambling, do not apply the concept of ribawi, do not provide goods or services that are haram because of the substances, do not trade that contains elements of uncertainty (gharar). The criteria for the selection of Sharia shares are based on Bapepam-LK Rule or OJK, no. II.K.1(www.idx.co.id, 23 September 2018). Therefore, it can be said that the shares that enter the criterion of JII are halal stocks, which do not contain ribawi element and have a capital structure of the company, most of which is notas debt. Therefore, as GCG is in line with JII characteristics, it is expected that there will be GCG of JII influence on CSR disclosure.

Table 1. Market capitalization of Jakarta Islamic Index 2010-2016 (Rp Billion)

\begin{tabular}{cccc}
\hline Year & $\begin{array}{c}\text { Market } \\
\text { Capitalization }\end{array}$ & Year & $\begin{array}{c}\text { Market } \\
\text { capitalization }\end{array}$ \\
\hline 2010 & $1,134,632.00$ & 2014 & $1,944,531.70$ \\
2011 & $1,414,983.81$ & 2015 & $1,737,290.98$ \\
2012 & $1,671,004.23$ & 2016 & $2,041,070.80$ \\
2013 & $1,672,099.91$ & & \\
\hline
\end{tabular}

Source: www.ojk.go.id 
Previous research conducted by Ramdhaningsih and Utama (2013) showed that managerial ownership, institutional ownership and profitability significantly influenced CSR disclosure. This research is supported by research conducted by Wiyuda and Pramono (2017) and Nugroho and Yulianto (2015) where institutional ownership influenced CSR disclosure. However Priantana and Yustian (2011) and Terzaghi (2012) found that institutional ownership and audit committees did not have any effect on CSR disclosure. Wiyuda and Pramono (2017) also found that boards of commissioners and profitability had positive effects on CSR disclosure area, while audit committee had a negative effect. Ningrum (2015) found that audit committees and stock ownership concentrated positively affected CSR disclosure. Rustiarini (2009) found that foreign ownership positively affected CSR disclosure, while Susilo (2015) found that the proportion of independent board of commissioners, managerial shareholdingsand concentrated shareholdings did not affect the extent of disclosure. Nugroho and Yulianto (2015) also found that the foreign ownership, size of the board of commissioners, independent board of commissioners, and audit committee did not affect CSR disclosure. Widowati et al. (2016) who examined the practice of Islamic Corporate Social Responsibility Disclosure (ICSRD) to JII showed that not all sample companies disclosed all items of disclosure that exist on the ICSRD. This was because the disclosure of annual reports made by the company tends to use the rules made by regulators; thus, some sharia-related items such as waqaf, usury, zakat, and others tend not to be disclosed in the annual report

According to the researchers' knowledge, the results of previous researches on the effect of GCG on CSR disclosure vary, where the GCG proxies used in the study also vary, whereas the studies on companies incorporated in JII have not been widely performed; thus there have not been consistent findings on this topic. Therefore, the researchers were motivated to conduct research on companies registered in JII period 20132016 related to this issue. The purpose of this study is to determine the effect of GCG on CSR disclosure on companies incorporated in JII period 2013-2016. GCG proxies used by the researchers in this study include the managerial ownership, institutional ownership, foreign ownership, size of the independent board, size of the audit committee and concentrated share ownership. The Corporate Social Responsibility Disclosure Index (CSRDI) refers to the Global Reporting Initiatives (GRI) indicator which consists of 79 items of disclosure.

\section{METHODS}

The type of data used in this study was secondary data that is the annual report of companies listed on the Indonesia Stock Exchange (IDX) incorporated in the JII in a row since 2013-2016. There are 23 companies listed consistently in the period of 2013-2016, and the data were retrieved from BEI.

In this research, sampling technique used was purposive sampling method, which determined the sample technique with certain considerations (Sugiyono, 2013). The sample selection criteria are as follows: Companies incorporated in JII were consistent in the period 2013-2016; Companies that published their annual reports in the period 2013-2016; Companies that disclosed their GCG and CSR.

This study used a quantitative approach to determine the significant effect of independent variables on the dependent variable. The variables in this research are as follows:

1. Managerial ownership is proxied by the formula:

$\mathrm{MO}=($ Number of shares owned by management/Total of shares outstanding) X $100 \%$

2. Institutional ownership is proxied by the formula:

$\mathrm{IO}=$ (Number of Shares owned by Institutional/Total of shares outstanding) X $100 \%$

3. Foreign ownership is proxied by the formula:

$\mathrm{FO}=$ (Number of shares owned by foreign parties/ Total of shares outstanding) X 100\%

4. The size of the independent commissioner board is proxied by the formula:

SIBC $=$ (Number of independent commissioners/ Number of commissioners) X100\%

5. The size of the audit committee where the indicator is used to measure the audit committee is the number of audit committee members in the sample company.

6. Concentrated share ownership is the ownership of more than $50 \%$ of shares in a company owned by one party (either an individual or an institution) (Susanti 
and Riharjo, 2013). This variable is measured using dummy variables, with a score of "1" if the firm has concentrated ownership and a score of " 0 " if the company's holdings are not concentrated.

7. Corporate Social Responsibility. Calculation of CSR Disclosure Index is formulated as follows:

CSRDI $=$ Number of items disclosed by the company/ 79

This variable is expressed in the Corporate Social Responsibility Disclosure Index (CSRDI) which refers to the GRI (Global Reporting Initiatives) indicator. GRI indicator consists of 79 items of disclosure. This is carried out because JII companies are companies that do not participate in sharia business; they are merged into JII based on company criteria set by National Sharia Board.

The data analysis used was multiple linear regression analysis using SPSS 24 application. Hypothesis testing in this research used multiple linear regression analysis. The regression model is as follows:

$Y=\beta_{0}+\beta_{1} X_{1}+\beta_{2} X_{2}+\beta_{3} X_{3}+\beta_{4} X_{4}+\beta_{5} X_{5}+\beta_{6} X_{6}+e$

Information: Y (CSR Disclosure); $\beta 0$ (Constants); $\beta 1$, $\beta 2, \beta 3, \beta 4, \beta 5, \beta 6$ (Coefficients of each variable);X1 (Managerial ownership); X2 (Institutional ownership); X3(Foreign ownership); X4 (Size of the independent commissioner board); X5 (Size of the audit committee); X6 (Concentrated share ownership); e (error).

The theoretical framework in this study is presented in Figure 1 with the following explanation: The more managerial ownership in the company, the more productive the actions of the manager in maximizing the value of the company and the higher the motivation to disclose the company's activities conducted (Rustiarini, 2009). In addition, in general, institutional investors are shareholders large enough to build a company's reputation. A high degree of institutional ownership will result in greater oversight efforts to deter opportunistic manager behavior. This means institutional ownership can improve the quality and quantity of voluntary disclosure. Likewise, the amount of foreign investors in the company will encourage the management to pay attention to the stakeholder's desire for the company to engage in CSR activities and disclose it to the public so that it can convince the community that the company's activities are in accordance with the norms and social values prevailing in the community (Nugroho and Yulianto, 2015).

The existence of independent commissioners is expected to be neutral to the policies made by the directors. The existence of an independent commissioner board is not affected by management; therefore, they tend to encourage companies to disclose broader information to their stakeholders (Ningrum, 2015). Thus, a greater proportion of the board of commissioners within the company can encourage a greater disclosure of social and environmental information. Meanwhile the audit committee influences the wide range of voluntary disclosure, so the larger the audit committee size, the more controlling and monitoring the management role will be to ensure transparency of voluntary disclosure (Nugroho and Yulianto, 2015). Likewise, for concentrated stock ownership, the more concentrated the stock of companies, both individuals and groups, the more expansive the disclosure of CSR (Susilo, 2015).

Based on the description of the theoretical framework, this research posits the following hypotheses:

H1 : Managerial ownership affects corporate CSR disclosure.

H2 : Institutional ownership affects corporate CSR disclosure.

H3 : Foreign ownership affects corporate CSR disclosure.

H4 : Size of the independent commissioners board affects corporate CSR disclosure.

H5 : Size of the audit committee affects corporate CSR disclosure.

H6 : Concentrated share ownership affects corporate CSR disclosure.

\section{RESULTS}

From the statistical test of the sample of JII companies, the following results were obtained:

\section{Descriptive Statistics}

Table 2 shows that CSR has the largest mean among the other variables, while the lowest mean is concentrated share ownership. However, institutional ownership has biggest standard deviation among other variables and the smallest standard deviation is concentrated share ownership. The mean of all variables are bigger than 
their standard deviation except managerial ownership. The mean value is greater than the standard deviation value, it indicates that the data distribution results are quite good.

\section{Multiple Linear Regression Test}

Table 3 shows that managerial ownership with a coefficient value of 0.435 is significant at $5 \%$, indicating that managerial ownership has an effect on CSR, thus H1 stating that managerial ownership has an effect on CSR is accepted. In addition, institutional ownership with coefficient value of 0,084 is significant at $5 \%$, indicating that institutional ownership has an effect on CSR; thus, H2 stating that ownership of institutional has an effect on CSR is accepted. Next, Table 3 shows that foreign ownership with a coefficient value of 0.143 is significant at $1 \%$, showing that foreign ownership affects CSR; thus, H3 stating that foreign ownership has an effect on CSR is accepted. However, the size of the independent commissioner board with coefficient value of -0.073 is significantly greater than 0.05 . This shows that the size of the independent commissioner board does not have effect on CSR; therefore, H4 stating that the size of independent commissioner board has an effect on CSR is rejected. Next, the size of the audit committee with coefficient value of -1.712 is significantly greater than 0.05 , indicating that the size of the audit committee does not have an effect on CSR; thus, $\mathrm{H} 5$ stating that the size of the audit committee has an effect on CSR is rejected. Finally, the concentrated share ownership with the coefficient value of -2.294 is significantly greater than 0.05 , indicating that concentrated share ownership does not have an effect on CSR; therefore, H6 stating that concentrated share ownership is rejected.

From the regression model in equation:

$\mathrm{Y}=\beta_{0}+\beta_{1} \mathrm{X}_{1}+\beta_{2} \mathrm{X}_{2}+\beta_{3} \mathrm{X}_{3}+\beta_{4} \mathrm{X}_{4}+\beta_{5} \mathrm{X}_{5}+\beta_{6} \mathrm{X}_{6}+\mathrm{e}$

Then, it got is as follow:

$\begin{aligned} \mathrm{Y}= & 63,487+(0,435) \mathrm{X} 1+(0,084) \mathrm{X} 2+(0,143) \mathrm{X} 3+ \\ & (-0,073) \mathrm{X} 4+(-1,712) \mathrm{X} 5+(-2,294) \mathrm{X} 6+\mathrm{e}\end{aligned}$

\section{Simultaneous Test (F)}

From Table 4, it is known that the $\mathrm{F}$ value of 3,338 is significant at level $1 \%$ so that it can be concluded that the regression model can be used to predict CSR disclosure. It also shows that the variables of managerial ownership, institutional ownership, foreign ownership, size of the independent commissioner board, size of the audit committee and concentrated share ownership have simultaneously affected CSR disclosure.

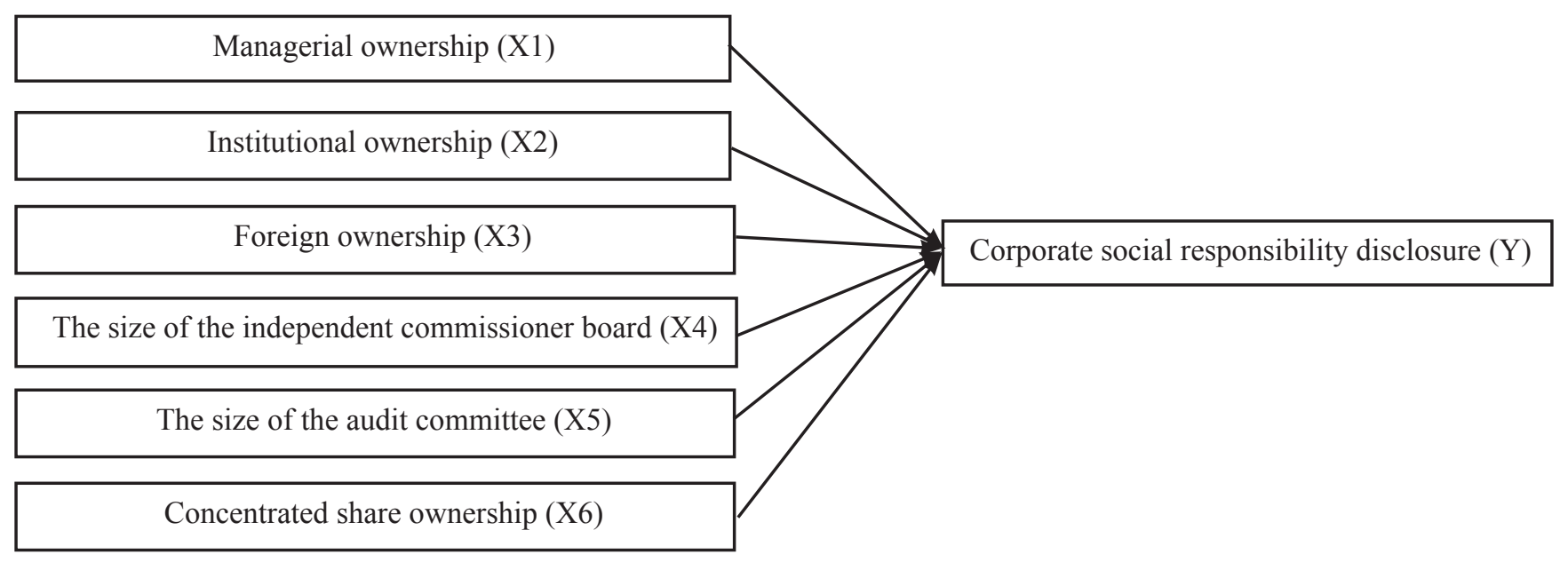

Figure 1.Reseacrh framework 
Table 2. Results of statistical descriptive test

\begin{tabular}{lcc}
\hline & Mean & Std. Deviation \\
\hline Managerial ownership & 1.3488 & 4.18290 \\
Institutional ownership & 38.1755 & 30.20906 \\
Foreign ownership & 32.3960 & 24.63130 \\
Size of the independent & 41.3472 & 13.82991 \\
commissioners board & & \\
Size of the audit committee & 3.67 & 1.223 \\
Concentrated share ownership & 0.51 & 0.503 \\
CSR & 62.456 & 11.496 \\
\hline
\end{tabular}

Table 3. Results of multiple linear regression test

\begin{tabular}{lccc}
\hline \multicolumn{1}{c}{ Model } & $\beta$ Coefficient & $\mathrm{t}$ & Sig. \\
\hline (Constant) & 63.487 & 10.720 & $* * * 0.000$ \\
$\begin{array}{l}\text { Managerial } \\
\text { ownership (X1) }\end{array}$ & 0.435 & 2.297 & $* * 0.024$ \\
$\begin{array}{l}\text { Institutional } \\
\text { ownership (X2) }\end{array}$ & 0.084 & 2.113 & $* * 0.038$ \\
$\begin{array}{l}\text { Foreign } \\
\text { ownership (X3) }\end{array}$ & 0.143 & 2.839 & $* * * 0.006$ \\
$\begin{array}{l}\text { Size of the } \\
\text { independent } \\
\text { commissioner } \\
\text { board (X4) }\end{array}$ & -0.073 & -0.870 & 0.387 \\
$\begin{array}{l}\text { She size of the } \\
\text { audit committee } \\
\text { (X5) }\end{array}$ & -1.712 & -1.813 & 0.073 \\
$\begin{array}{l}\text { Concentrated } \\
\text { share ownership } \\
\text { (X6) }\end{array}$ & & & \\
\hline $\begin{array}{l}\text { Note: ***) significant at the level of 1\%; } \\
\text { the level of 5\% }\end{array}$ & & & \\
& & & \\
\end{tabular}

Table 4. Result of simultaneous significance test (Test F)

\begin{tabular}{lcc}
\hline Model & $\mathrm{F}$ & Sig. \\
\hline Regression residual total & 3.338 & $* * * 0,005$ \\
\hline
\end{tabular}

Note:***Significant at the level $1 \%$

\section{Determination Coefficient ( R2)}

In Table 5, it can be seen that the adjusted R2 is 0.134 , meaning that $13.4 \%$ the variation of corporate CSR is influenced by variations of independent variables of managerial ownership, institutional ownership, foreign ownership, size of the independent commissioners board, size of audit committee, and concentrated share ownership whereas the remaining $86.6 \%$ is influenced by other variables outside these variables.
Table 5. Result of determination coefficient $\mathrm{R}^{2}$

\begin{tabular}{lc}
\hline Model & Adjusted R Square \\
\hline 1 & .134 \\
\hline
\end{tabular}

\section{The Effects of Managerial Ownership on CSR Disclosure}

The results of this study found that managerial ownership positively affects CSR disclosure. This can be explained by the increase of share ownership by managers, so it is expected that managers will act in harmony with the interests of stakeholders so that they are careful in making decisions as well as forming responsibility to the shareholders and the surrounding community. Thus, it is expected that they can also express corporate social responsibility. The results of this study support the research conducted by Susanti and Riharjo (2013) and Ramdhaningsih and Utama (2013) with the results of their research stating that managerial ownership affects CSR. With the existence of managerial ownership, it is expected to reduce the actions of managers in manipulating earnings, being more careful in making decisions and forming responsibilities to shareholders and the community.

\section{The Effects of Institutional Ownership on CSR Disclosure}

The next result is institutional ownership which positively influences CSR disclosure. It can be explained that the greater the institutional ownership, the greater the oversight of management. Institutional ownership may require companies to increase CSR disclosure, as large institutional ownership is better in monitoring management performance. The results of this study are supported by research conducted by Ramdhaningsih and Utama (2013), Ningrum (2015) and Nugroho and Yulianto (2015) with the results of their research stating that institutional ownership affects CSR. Institutional ownership can improve the quality and quantity of voluntary disclosure as investors are responsible for the implementation of GCG.

\section{The Effects of Foreign Ownership on CSR Disclosure}

Another result found in this study is that foreign ownership positively affects CSR disclosure, indicating that foreign ownership in Indonesia is also concerned with social problems in Indonesia. The results of this 
research support Rustriarini research (2009) where the results of this study support agency theory which shows that foreign ownership in the company is able to make the monitoring process better so that information owned by the management can be disseminated thoroughly to stakeholders. The results of this study also support previous research conducted by and Nugroho and Yulianto (2015) who conducted research on JII stocks.

\section{The Effects of the Size of the Independent Commissioner Board on CSR Disclosure}

While the size of the independent commissioner board does not have an effect on CSR disclosure, it can be explained that the size of the board and presence of more independent commissioner in the ranks of independent commissioner do not directly provide more social disclosure items that should be disclosed. The existence or proportion of the independent commissioner board cannot influence the decision-making process because they do not have relationship to the daily activities of the company. The results of this study support research conducted by Djuitaningsih and Marsyah (2012), Susilo (2015) and Nugroho and Yulianto (2015).

\section{The Effects of the Size of the Audit Committee on CSR Disclosure}

A minimum of 3 members is the number of audit committees according to Kep-339/BEI/07-2001 while from the results of this study show that the companies incorporated in JII already on average have the total number of members that comply with the rules, but the larger the audit committee in monitoring the management, the more extensive the assurance of the transparency of CSR disclosure (Ningrum, 2015). The size of audit committees does not have any effects on CSR because they only perform routine tasks, such as reviewing reports and selection of external auditors, and not critically questioning and analyzing in depth the conditions of control and execution of responsibilities by management. The results of this study support researches conducted Terzaghi (2012), Priantana and Yustian (2011) and Nugroho and Yulianto (2015).

\section{The Effects of Concentrated Share Ownership on CSR Disclosure}

As for the concentrated ownership of shares that have no effects on CSR disclosure, the results of this study support research conducted by Susilo (2015) where concentrated share ownership cannot reduce the issue of conflict of interest between shareholders and management. However, the results of this study do not support the research of Ningrum (2015) in which concentrated share ownership positively affects CSR corporate disclosure.

\section{Managerial Implications}

The study found that managerial ownership, institutional ownership and foreign ownership have positive effects on CSR disclosure, while the size of independent commissioners board, size of the audit committee and concentrated share ownership have no effects on CSR disclosure of JII, period of 2013-2016.

Party of Company Management

In general, the company has implemented good corporate governance or GCG principles consistently across all levels of the company's operations to create a sound decision-making process, improved performance and accountability as well as fulfillment of stakeholder expectations although there are still some companies have not complied with the principles of good governance principles of GCG efficiently. Therefore, to create a healthy climate in the implementation of GCG in the company, the company should involve all stakeholders. Involvement of all parties is necessary in compliance with GCG principles. The significant influence of managerial ownership, institutional ownership and foreign ownership indicates that there is already an alignment of interests between owners and managers. Managers have also taken productive actions in maximizing corporate value, and further motivate the company's management to disclose social responsibility so as to build a good reputation for the company.

In addition, based on the findings of this study, the size of the independent commissioner board, size of the audit committees and concentrated shareholdings do not have effects on CSR disclosure, indicating that the size of the independent commissioner board and size of the audit committee do not guarantee CSR disclosure. It is possible that the audit committee and independent commissioner boards do not affect the company's decision-making because they are not involved in routine company operations (Susilo, 2015). Therefore, management should include them in the company's decision making so that the company's decision to 
be taken is more objective and the audit committee can oversee management in terms of the preparation of credible financial statements so that voluntary disclosure will be achieved. The obligation to apply GCG principles should have a positive influence on the quality of financial statements as well as published annual reports. Company management needs to consider concentrated ownership of stocks where the more concentrated shareholdings, the wider level of CSR disclosure to be reported in the annual report.

Investors' party

Investors need to know the extent to which the company discloses CSR information in its annual report as it relates to the prospects of the company in the future as well as shows more value to the company for its concern about the economic, social and environmental impacts arising from the company's activities. The CSR disclosure indicates that companies implementing CSR are expected to be responded positively by market participants, and CSR publications demonstrate the company's commitment to improve transparency about long-term corporate performance and risk management and financial statements with CSR disclosure and accounting information power, and to give investors confidence in assessing risk and return expected (Awuy et al. 2016).

\section{CONCLUSIONS AND RECOMMENDATIONS}

\section{Conclusions}

The results of this study found that managerial ownership, institutional ownership, and foreign ownership have positive effects on CSR disclosure in JII period of 2013-2016 while the size of the independent commissioner board, size of audit committee and concentrated share ownership do not have effects on CSR disclosure. The results of this study indicate that companies incorporated in JII have not fully implemented GCG mechanism so that CSR disclosure has not been fully exercised.

\section{Recommendations}

Companies incorporated in JII are those that meet the criteria of sharia shares based on Bapepam-LK or OJK regulations, but not companies whose business is purely sharia or sharia-based. For further research, it is advisable to conduct research on companies whose business is pure sharia by using Islamic Corporate Social Responsibility Disclosure Index (ICSRD) so that it will depict the GCG of the actual sharia-based companies.

\section{REFERENCES}

Andypratama LW, Mustamu RH, 2013. Penerapan Prinsip-prinsip-prinsip good corporate governance pada perusahaan keluarga: studi deskriptif pada distributor makanan. Agora $1(1): 1-11$.

Awuy VP, Sayekti Y, Purnamawati I, 2016. Pengaruh pengungkapan corporate social responsibility (CSR) terhadap earnings response coefficient (ERC) (suatu studi empiris pada perusahaan pertambangan yang terdaftar di bursa efek indonesia pada tahun 2010-2013. Jurnal Akuntansi dan Keuangan 18(1):15-26.

[BAPEPAM] Badan Pengawas Pasar Modal dan Lembaga Keuangan. 2010. Kajian tentang Pedoman Good Corporate Governance Di Negara-Negara Anggota ACMF. Jakarta: Bapepam.

Djunaedi RR, Baga LM, Krisnatuti D. 2016. Efektivitas implementasi corporate social responsibility PT. ABC. Jurnal Aplikasi Bisnis dan Manajemen 1(2):118-127.

Djuitaningsih T, Marsyah WA. 2012. Pengaruh manajemen laba dan mekanisme corporate governance terhadap corporate social responsibility. Jurnal Media Riset Akuntansi 2(2):187-211.

IDX. 2018. Islamic Stocks. http://www.idx.co.id/en-us/ idx-islamic/islamic-product/. [September, 23th 2018].

Ismanto K. 2009. Manajemen Syariah, Implementasi TQM Dalam Lembaga Keuangan Syariah. Cetakan I. Yogyakarta: Pustaka Pelajar.

Lindawati, ASL, Puspita, ME. 2015. Corporate social responsibility: implikasi stakeholder dan legitimacy gap dalam peningkatan kinerja perusahaan Jurnal Akuntansi Multiparadigma 6(1):157-174.

Nugroho, MZ, Yulianto A. 2015. Pengaruh profitabilitas dan mekanisme corporate governance terhadap pengungkapan csr perusahaan terdaftar JII 2011-2013. Accounting Analysis Journal 4(1). https://doi.org/10.15294/aaj.v4i1.7829. 
Ningrum LP. 2015. Pengaruh faktor-faktor good corporate governance terhadap pengungkapan corporate social responsibility pada perusahaan manufaktur yang terdaftar di bursa efek indonesia periode 2011-2013 [skripsi]. Surakarta: Universitas Muhammadiyah Surakarta.

Nussy TM. 2013. Corporate governance dan entitas terhadap pengungkapan corporate social responsibility. Jurnal Keuangan dan Perbankan 17(1):1-10.

OJK. 2017. http://www.ojk.go.id/id/kanal/syariah/ data-dan-statistik/saham-syariah/Pages/ Statistik-Saham-Syariah---Januari-2017.aspx. [02 Februari 2018].

Priantana RD, Yustian A. 2011. Pengaruh struktur good corporate governance terhadap pengungkapan corporate social responsibility pada perusahaan keuangan yang terdaftar di bursa efek Indonesia. Jurnal Telaah \& Riset Akuntansi 4(1):65-78.

Ramdhaningsih, Amalia, Utama IMK. 2013.Pengaruh indikator good corporate governance dan profitabilitas pada pengungkapan corporate social responsibility. E - Jurnal Akuntansi Universitas Udayana 3(3):65-82.

Rustiarini NW. 2009. Pengaruh struktur kepemilikan saham pada pengungkapan corporate social responsibility. Jurnal Riset Akuntansi 6(1):124.

Suaryana A, Febriana. 2012. Faktor-faktor yang mempengaruhi kebijakan pengungkapan tanggung jawab sosial dan lingkungan pada perusahaan manufaktur di bursa efek Indonesia. Jurnal Ilmiah Akuntansi dan Bisnis 7(1).
Sugiyono. 2013. Metode Penelitian Bisnis. Bandung. Alfabeta.

Sukasih A, Sugiyanto E. 2017. Pengaruh struktur good corporate governance dan kinerja lingkungan terhadap pengungkapan corporate social responsibility. Riset Akuntansi dan Keuangan Indonesia 2(2):121-131.

Susanti S, Riharjo IB. 2013. Pengaruh good corporate governance terhadap corporate social responsibility pada perusahaan cosmetics and household Jurnal Ilmu dan Riset Akuntansi 1(1):152 - 167.

Susilo MS. 2015. Pengaruh Good Corporate Governance Terhadap Luas Pengungkapan Corporate Social Responsibility. Jurnal Ilmu \& Riset Akuntansi 4(5).

Terzaghi MT. 2012. Pengaruh earning management dan mekanisme corporate governance terhadap pengungkapan tanggung jawab sosial perusahaan manufaktur yang terdaftar di Bursa Efek Indonesia.Jurnal Ekonomi dan Akuntansi 2(1).

Widowati AI, Surjawati, Oktoriza LA, Dian ITL. 2016. Praktik islamic corporate social responsibility disclosure (studi kasus terhadap perusahaan yang terdaftar di Jakarta Islamic Indeks. Jurnal Dinamika Sosial Budaya 18(2):207-217. http:// dx.doi.org/10.26623/jdsb.v18i2.570

Wiyuda A, Pramono H. 2017. Pengaruh good corporate governance, karaketeristik perusahaan terhadap luas pengungkapan corporate social responsibility pada perusahaan terdaftar di BEI. Kompartemen XV(1):12-25. 